\title{
The Effect of Hot Water Treatment of Rooted Grapevine Nursery Stock on the Survival of the Root-knot Nematode, Meloidogyne javanica (Nematoda: Heteroderidae)
}

\author{
R. Knoetze
}

Agricultural Research Council, Infruitec-Nietvoorbij, Private Bag X5026, Stellenbosch 7599, South Africa

Submitted for publication: August 2019

Accepted for publication: November 2019

Key words: Grapevine, Meloidogyne, hot water treatment, root-knot nematode, control

\begin{abstract}
Root-knot nematodes (Meloidogyne spp.) are endoparasites which cause severe losses in grapevine. To ensure economically viable grape production, it is important that nurseries produce rooted nursery material free of plant-parasitic nematodes. Hot water treatment (HWT) at $50^{\circ} \mathrm{C}$ for 45 min to eliminate root-knot nematode (RKN) from rooted nursery material was investigated as a method to ensure nematode free plant material. Rooted grapevine rootstocks known to be susceptible (US 8-7 and 110 Richter), moderately resistant (1103 Paulsen and $143 \mathrm{~B}$ ) and resistant (Ramsey) to Meloidogyne javanica were artificially infested by inoculating them with RKN eggs and larvae. After one growing season, the vines were lifted, shoots and root systems trimmed and subjected to different $\mathrm{HWT}$ regimes viz. $50^{\circ} \mathrm{C}$ for $45 \mathrm{~min}$ and $55^{\circ} \mathrm{C}$ for $20 \mathrm{~min}$, while some were left as untreated controls. To evaluate plant response, each vine was planted in a pot, together with a three-week old tomato seedling as an indicator of root-knot nematode infestation. The tomato plants were removed after 12 weeks and their roots examined for the presence of $M$. javanica galls and egg masses. At the end of the growing season, the effects of the treatments on plant growth were assessed by determining total shoot and root mass. The results demonstrated that $\mathrm{HWT}$ at $55^{\circ} \mathrm{C}$ for 20 min significantly reduced the nematode populations in the rooted stocks, but did not eliminate the nematodes from the roots since indicator plants from HWT vines still supported a small number of galls. HWT at $55^{\circ} \mathrm{C}$ for $20 \mathrm{~min}$ also reduced the level of infestation of $\mathrm{RKN}$ in grapevine planting material, but resulted in a significant reduction in growth.
\end{abstract}

\section{INTRODUCTION}

Root-knot nematodes (Meloidogyne spp.) (Tylenchida: Heteroderidae) are endoparasites which cause severe losses in grapevine. They penetrate the roots to feed, inducing the formation of characteristic root galls. Heavy infestation weakens the root system, restricting the ability of roots to absorb water and nutrients, leading to reduced vigour and yield (Storey et al., 2017). Nematode control in established vineyards is costly and untreated infestations can reduce the productive lifespan of a vineyard. Providing nematode-free planting material to growers is key to ensure economically viable grape production. Although nurseries use soil fumigation and chemical control throughout the year, endoparasites like root-knot nematodes (RKN) can still be transmitted by infested rooted plant material.

Hot water treatment (HWT) is an effective and practical method for the control of a number of grapevine pests and diseases in dormant grapevine cuttings and young rooted vines (Von Broembsen \& Marais, 1978; Suatmadji, 1982; Loubser \& Höppner, 1986; Fourie \& Halleen, 2004;
Gramaje et al., 2009). Barbercheck (1986) showed that HWT eliminated root-knot nematodes from grapevine nursery stock, but concerns have been raised that this HWT regime may not be sufficient to ensure that no viable RKN adults, juveniles or eggs survive in the roots of treated plants.

The South African Plant Certification Scheme for wine grapes requires plant material to be visually free of RKN infestation for certification, whilst HWT for eradication of RKN in rooted grapevine material is not prescribed in the Standard Operating Procedure (SOP) for Grapevines pertaining to rejections of graft combinations for visual symptoms of RKN (https://www.gov.za/documents/plantimprovement-act-south-african-plant-certification-schemewine-grapes-amendment). The current SOP does prescribe HWT at $50^{\circ} \mathrm{C}$ for $45 \mathrm{~min}$ to eliminate crown gall and aster yellows phytoplasma, or $\mathrm{HWT}$ at $55^{\circ} \mathrm{C}$ for $5 \mathrm{~min}$ to remove other superficial pathogens and pests. Confirmation of the efficacy of $\mathrm{HWT}$ at $50^{\circ} \mathrm{C}$ for $45 \mathrm{~min}$ for the elimination of RKN from rooted vines is important for the Vine Improvement

Corresponding author: E-mail address: knoetzer@arc.agric.za

Acknowledgements: The authors would like to thank the Agricultural Research Council, Winetech and the South African Table Grape Industry for funding the research, and B. Sokomani, D. Hinds and C. Paulse for technical assistance 
Association before revising current regulations and SOPs.

The aim of this study was to test the efficacy of HWT for eliminating RKN from rooted nursery material, as well as the impact of HWT on the initial growth of the treated plants.

\section{MATERIALS AND METHODS}

\section{Inoculation of grapevine rootstocks}

Grapevine rootstocks known to be susceptible (US 8-7 and 110 Richter), moderately resistant (1103 Paulsen and 143 B) and resistant (Ramsey) to Meloidogyne javanica (Treub, 1885) Chitwood, 1949 were grafted with Chenin blanc, callused and rooted at a commercial grapevine nursery (Vititec, Paarl). Rooted vines were planted in sandy soil in planting bags and kept in a glasshouse, set at $25^{\circ} \mathrm{C}$. Twentyone representatives of each rootstock were inoculated with $M$. javanica on four occasions during the 2017/18 growing season by pipetting $5 \mathrm{ml}$ of a suspension containing approximately 3000 eggs and juveniles into two holes made in the soil, approximately 1.5 to $2.0 \mathrm{~cm}$ from the plant stem. Inoculation sites were covered by pressing the soil mixture back into place. Seven representatives of each rootstock were not inoculated (control plants) and kept separately to avoid contamination. After the first growing season, root samples were collected and pooled for each rootstock type, where-after 3 x $10 \mathrm{~g}$ subsamples were used to determine the level of infestation. The number of eggs per gram of roots was determined by using Riekert's adapted $\mathrm{NaOCl}$ method (Riekert, 1995), whereby the roots were cut into $10-\mathrm{mm}$ pieces and shaken thoroughly for $4 \mathrm{~min}$ in a $1 \% \mathrm{NaOCl}$ solution. The solution was decanted through stacked sieves (75- and 25- $\mu \mathrm{m}$-aperture) and washed thoroughly before the eggs and juveniles were collected from the $25-\mu \mathrm{m}$-aperture sieve.

\section{Hot water treatment}

After the first growing season, the vines were lifted, shoots trimmed to three buds and the root systems trimmed to approximately $150 \mathrm{~mm}$. The plants were then packed into plastic bins, covered with sawdust and stored in a cold room at $5^{\circ} \mathrm{C}$. Plants from each rootstock were divided into 4 groups, constituting the different treatments, which were: i) infected plants, no HWT; ii) infected plants, HWT at $50{ }^{\circ} \mathrm{C}$ for $45 \mathrm{~min}$; iii) infected plants, HWT at $55^{\circ} \mathrm{C}$ for $20 \mathrm{~min}$ and iv) non-infected plants; no HWT. There were seven replications of each treatment. Plants were submersed in thermostatically controlled hot water baths, set at the predetermined temperatures. Immediately after treatment the vines were immersed in a cold water bath at $15^{\circ} \mathrm{C}$ for $15 \mathrm{~min}$. After treatment, the vines were planted immediately and moved to a glasshouse at $25^{\circ} \mathrm{C}$.

\section{Evaluation of the efficacy of HWT}

To evaluate treatment efficacy, each vine was planted in a plastic pot containing sterilized sandy soil and placed in a glasshouse at $25^{\circ} \mathrm{C}$. The pots were arranged in a randomized block design, consisting of seven blocks, with 20 pots in each block. The vines were drip-irrigated with filtered water ( $5 \mu \mathrm{m}$ filter) to avoid external contamination, as well as cross contamination between pots. Three days later, a three-week old tomato seedling (cv. Moneymaker) was planted next to each vine as indicator of RKN infestation.

Twelve weeks later, the tomato plants were removed, their roots stained with a $0.1 \%$ food dye containing Ponceau 4R (Damasceno et al., 2016) for easier detection and then examined for the presence of root-knot nematode galls and egg masses. The number of galls and/or egg masses resulting from each grapevine-tomato combination was recorded. A value of 100 galls was assigned to heavily infested root systems, as it was not possible to accurately count the number of galls present.

\section{Evaluation of growth response}

To evaluate plant response to the HWT, budding and sprouting of the plants after planting were monitored on a weekly basis. Five months after planting (February 2019) the grapevines were removed from their pots, leaves removed and the root systems rinsed with water to be free of soil. Shoot length and fresh shoot weight were measured immediately, but the root weight was determined after overnight (12 h) drying at room temperature.

\section{Data analyses}

The experimental design was a randomised block design with seven block replications. The treatment design was a factorial with two factors, rootstocks with five levels and hot water treatment with four levels. To interpret the number of galls and/or egg masses on tomato root systems the data was subjected to an ANOVA using General Linear Models Procedure (PROC GLM) of SAS software (Version 9.4; SAS Institute Inc, Cary, USA). The kurtosis value and symmetrical histogram in the Univariate Procedure (PROC UNIVARIATE) of SAS Software indicated normality of standardized residuals. Fisher's least significant difference was calculated at the $5 \%$ level to compare treatment means (Ott \& Longnecker, 2001). To analyse growth variables of infested plants, the data was subjected to an ANOVA using General Linear Models Procedure (PROC GLM) of SAS software (Version 9.4; SAS Institute Inc, Cary, USA). The Shapiro-Wilk test confirmed normality of the standardized residuals (Shapiro \& Wilk, 1965). Fisher's least significant difference was calculated at the $5 \%$ level to compare treatment means (Ott \& Longnecker, 2001).

\section{RESULTS AND DISCUSSION}

\section{Infection rates}

The grapevines were successfully infested with $M$. javanica during the first growing season. Table 1 shows the number of eggs gram roots ${ }^{-1}$ detected at the end of the growing season. The results confirmed that US 8-7 and 110 Richter were the most susceptible to M. javanica, with 1103 Paulsen and 143 B being moderately susceptible and Ramsey the least susceptible.

\section{Efficacy of HWT}

Data analysed with a factorial ANOVA showed significant differences $(p<0.0001)$ when comparing the number of galls and/or egg masses on roots of tomato indicator plants, planted next to $M$. javanica infected grapevines subjected to different hot water regimes (Table 2). The presence of nematodes in a tomato plant was considered proof that the 
TABLE 1

Infestation rates of different rootstock types with Meloidogyne javanica.

\begin{tabular}{lc}
\hline Rootstock & $\begin{array}{c}\text { Average RKN eggs } \\
\text { gram roots }^{-1}\end{array}$ \\
\hline US 8-7 & 145.0 \\
Richter 110 & 49.3 \\
1103 Paulsen & 10.7 \\
$143-B$ & 9.0 \\
Ramsey & 8.7 \\
\hline
\end{tabular}

HWT did not successfully eradicate all the RKN present in the roots of the grapevine plant. The number of RKN that survived in all of the HWT plants was significantly lower than in the untreated control, but it was not zero, except in the vines grafted onto Ramsey rootstocks. This means that a small number of the nematodes was not killed by the treatments and were able to produce eggs which could hatch and infest the tomato plants. Suatmadji (1982) also found that control by HWT $\left(51.7^{\circ} \mathrm{C}\right.$ for $\left.5 \mathrm{~min}\right)$ was incomplete, as indicator plants planted next to HWT vines supported a small number of galls. This was attributed to the fact that immature nematodes were imbedded in young galls consisting of tightly packed cells, which may contribute to the nematodes surviving the treatment. Barbercheck (1986) found that HWT eliminated $M$. javanica from grapevine nursery stock, but it must be considered that, in that case, tomato plants were not used as indicators of RKN viability.

Eradication of the nematodes in the Ramsey material is attributed to the fact that the material was the least infested before the commencement of HWT. Thus, the combination of plant resistance and HWT seems to have contributed to effective eradication of the nematodes on this occasion. Conversely, the combination of the most susceptible rootstock (US 8-7) with the treatment of $50^{\circ} \mathrm{C}$ for $45 \mathrm{~min}$, was the least effective of the treatment combinations (Table 2).
Considering the combined treatment averages of all the rootstocks, it is evident that the treatment of $55^{\circ} \mathrm{C}$ for $20 \mathrm{~min}$ was significantly more effective in reducing the nematode population in infested rootstocks than the $50^{\circ} \mathrm{C}$ for $45 \mathrm{~min}$ treatment (Table 2).

\section{Growth response of vines to HWT}

Cumulative sprouting percentages of the vines over a 7-week period indicated that untreated plants started sprouting in the first week after planting, whilst treated plants started sprouting in the second week. Overall, budburst of plants treated at $50^{\circ} \mathrm{C}$ for $45 \mathrm{~min}$ was delayed by one week, whilst budburst of plants treated at $55^{\circ} \mathrm{C}$ for 20 min was effectively delayed for two weeks. The lowest sprouting percentage was recorded for vines grafted onto Ramsey rootstocks treated at $55^{\circ} \mathrm{C}$ for $20 \mathrm{~min}(57 \%)$, while all the vines grafted onto Ramsey rootstocks treated at $50^{\circ} \mathrm{C}$ for $45 \mathrm{~min}$ sprouted within 3 weeks.

Data analysed with a factorial ANOVA showed no significant differences between the growth responses of different rootstocks, but the differences between treatments were highly significant $(\mathrm{p}<0.0001)$. Table 3 shows the plant responses with regard to shoot length, shoot weight and root weight, regardless of rootstock. The best growth was observed in plants treated at $50^{\circ} \mathrm{C}$ for $45 \mathrm{~min}$, but it did not differ significantly from infected plants that were not subjected to HWT. Studies carried out by Graham (2007) showed that cuttings grown in cool climates in New Zealand were susceptible to damage at $50^{\circ} \mathrm{C}$ for $30 \mathrm{~min}$, but evidence suggests that tolerance of plants to HWT is affected by the climate in which the cuttings are grown (Waite \& Morton, 2007). Von Broembsen \& Marais (1978) found that treatment for $15 \mathrm{~min}$ to $60 \mathrm{~min}$ at $50^{\circ} \mathrm{C}$ resulted in no phytotoxic effects to dormant vines, but Loubser \& Höppner (1986) reported that plant mass increase as well as root mass of HWT $\left(50^{\circ} \mathrm{C}\right.$ for $15 \mathrm{~min}$ ) vines were significantly lower than those of untreated plants.

Shoot lengths and shoot weights of infested plants treated at $50^{\circ} \mathrm{C}$ for 45 minutes were significantly more than those of uninfested, untreated plants. This anomalous result can be attributed to the fact that closer

TABLE 2

Number of galls/egg sacs detected on roots of tomato indicator plants, planted next to Meloidogyne javanica infected grapevines, subjected to different hot water regimes. Data are means of seven replications. Means in the same column followed by the same letter do not differ significantly according to Fisher's LSD test $(\mathrm{P}>0.05)$.

\begin{tabular}{|c|c|c|c|c|c|c|}
\hline Treatment & US 8-7 & 110 Richter & 1103 Paulsen & $143 \mathrm{~B}$ & Ramsey & $\begin{array}{l}\text { Combined } \\
\text { treatment } \\
\text { average }\end{array}$ \\
\hline $\begin{array}{l}\text { Infested } \\
\text { No HWT }\end{array}$ & $* 100.00 \mathrm{a}$ & $* 100.00 \mathrm{a}$ & $* 100.00 \mathrm{a}$ & $* 100.00 \mathrm{a}$ & $16.14 \mathrm{bc}$ & $83.23 \mathrm{a}$ \\
\hline $\begin{array}{l}\text { Infested } \\
50^{\circ} \mathrm{C} \text { for } 45 \mathrm{~min}\end{array}$ & $29.00 \mathrm{~b}$ & $0.86 \mathrm{~d}$ & $0.86 \mathrm{~d}$ & $8.14 \mathrm{~cd}$ & $0.00 \mathrm{~d}$ & $7.77 \mathrm{~b}$ \\
\hline $\begin{array}{l}\text { Infested } \\
55^{\circ} \text { for } 20 \mathrm{~min}\end{array}$ & $1.43 \mathrm{~d}$ & $0.00 \mathrm{~d}$ & $0.29 \mathrm{~d}$ & $0.14 \mathrm{~d}$ & $0.00 \mathrm{~d}$ & $0.37 \mathrm{c}$ \\
\hline $\begin{array}{l}\text { Not infested } \\
\text { No HWT }\end{array}$ & $0.00 \mathrm{~d}$ & $0.00 \mathrm{~d}$ & $0.00 \mathrm{~d}$ & $0.00 \mathrm{~d}$ & $0.00 \mathrm{~d}$ & $0.00 \mathrm{c}$ \\
\hline
\end{tabular}

*A value of 100 was assigned to heavily infested root systems, as it was not possible to accurately count the number of galls present. 
TABLE 3

Mean shoot length, shoot weight and root weight of Meloidogyne javanica infested grapevines, subjected to different hot water regimes. Means in the same column followed by the same letter do not differ significantly according to Fisher's LSD test $(\mathrm{P}>0.05)$.

\begin{tabular}{|c|c|c|c|}
\hline Treatment & Shoot length (mm) & Shoot weight (g) & Root weight (g) \\
\hline $\begin{array}{l}\text { Infested } \\
50^{\circ} \mathrm{C} \text { for } 45 \mathrm{~min}\end{array}$ & $1222.54 \mathrm{a}$ & $11.79 \mathrm{a}$ & $91.17 \mathrm{a}$ \\
\hline $\begin{array}{l}\text { Infested } \\
\text { No HWT }\end{array}$ & $1111.73 \mathrm{ab}$ & $10.25 \mathrm{ab}$ & $88.89 \mathrm{a}$ \\
\hline $\begin{array}{l}\text { Not infested } \\
\text { No HWT }\end{array}$ & $1004.24 \mathrm{~b}$ & $9.50 \mathrm{~b}$ & $85.10 \mathrm{a}$ \\
\hline $\begin{array}{l}\text { Infested } \\
55^{\circ} \text { for } 20 \mathrm{~min}\end{array}$ & $808.34 \mathrm{c}$ & $6.53 \mathrm{c}$ & $54.60 \mathrm{~b}$ \\
\hline
\end{tabular}

inspection of the vines revealed dark-brown to black discoloration in the xylem of the root crown and basal rootstock of the vines. Fungal isolation (performed at ARC Infruitec-Nietvoorbij) detected the presence of the pathogens Phaeoacremonium aleophilum Gams, Crous, Wingfield \& Mugnai (Diaporthales: Togniniaceae) and Pleurostomophora richardsiae (Nannf.) Mostert, Gams \& Crous (Calosphaeriales: Pleurostomataceae), both of which are associated with Petri disease of grapevines. Fourie \& Halleen (2004) found that HWT $\left(30 \mathrm{~min}\right.$ at $\left.50^{\circ} \mathrm{C}\right)$ of dormant nursery material were effective in reducing fungal infection levels in nursery plants. It is therefore possible that HWT reduced the severity of the fungal infection in these vines, leading to the masking of any growth retardation that may have resulted from $\mathrm{HWT}$ at $50^{\circ} \mathrm{C}$ for $45 \mathrm{~min}$.

The combined growth of plants treated at $55^{\circ} \mathrm{C}$ for $20 \mathrm{~min}$ was significantly less than with all of the other treatments. Gramaje et al. (2009), when investigating HWT against Petri disease pathogens, found that there was little variability in the percentages of sprouting and shoot weight after HWT, with the exception of the HWT at $54^{\circ} \mathrm{C}$ in which the highest reduction was obtained. In this study, it was evident from sprouting percentages, shoot length, shoot weight and root weight that vines were damaged by HWT at $55^{\circ} \mathrm{C}$ for $20 \mathrm{~min}$.

\section{CONCLUSIONS}

This research showed that $\mathrm{HWT}$ at $50^{\circ} \mathrm{C}$ for 45 minutes greatly reduced the level of infestation of RKN in grapevine planting material, particularly when RKN infestation levels were low, but it did not eradicate RKN in all instances. HWT at $55^{\circ} \mathrm{C}$ for $20 \mathrm{~min}$ also reduced the level of infestation of RKN in grapevine planting material, but resulted in a significant reduction in growth and therefore cannot be recommend for the treatment of rooted grapevine nursery material.

Since HWT at $50^{\circ} \mathrm{C}$ for $45 \mathrm{~min}$ did not completely eliminate RKN from rooted material, the unqualified revision of current regulations and operating procedures cannot be recommended to the Vine Improvement Association. However, HWT can be successfully implemented in nurseries as an added measure to reduce nematode infestation, but only if due consideration is given to the prevention of infestation of rooted material with RKN. An integrated strategy for the proactive management of RKN in grapevine nurseries, which includes practices such as the filtering of irrigation water, sterilization of growing medium, general sanitation practices and the use of HWT, is advocated to provide RKNfree planting material, which will ultimately save costs for nematode control in established vineyards and prolong the productive lifespan of vineyards.

\section{LITERATURE CITED}

Barbercheck, M., 1986. Control of Meloidogyne javanica in dormant grapevine nursery stock. Phytophylactica 18, 39-40.

Damasceno, J.C.A., Soares A.C.F., de Jesus F.N. \& Castro J.M.C., 2016 Root-knot nematode staining with artificial food dyes. Nematoda 3, 1-5. http://dx.doi.org/10.4322/nematoda.01816

Fourie, P.H. \& Halleen, F., 2004. Proactive control of Petri disease of grapevine through treatment of propagation material. Plant Dis. 88, 1241-5. https://doi.org/10.1094/PDIS.2004.88.11.1241

Graham, A., 2007. Hot water treatment of grapevine rootstock cuttings grown in a cool climate. Phytopathol. Mediterr. 46, 124.

Gramaje, D., Armengol, J., Salazar, D., López-Córtes I. \& Garclá-Jiménez J., 2009. Effect of hot-water treatments above $50^{\circ} \mathrm{C}$ on grapevine viability and survival of Petri disease pathogens. Crop Prot. 28, 280-285. https://doi. org/10.1016/j.cropro.2008.11.002

Loubser, J.T. \& Höppner, G.F., 1986. Control of lesion nematodes, Pratylenchus spp., in grapevine nursery material by immersion in fenamiphos solutions and hot water. South Afr. J. Enol. Vitic. 7, 3-5.

Ott, R.L. \& Longnecker, M., 2001. An introduction to statistical methods and data analysis 5th Edition. Belmont, California, Duxbury Press.

Riekert, H.F., 1995. An adapted method for extraction of root-knot nematode eggs from maize root samples. Afr. Plant Prot. 1, 41-43.

Shapiro, S.S., Wilk, M.B. \& Chen, H.J., 1968. A comparative study of various tests for normality. J. Am. Stat. Assoc. 63(324), 1343-1372.

Storey, S.G., Malan, A.P. \& Hugo, H.J., 2017. Nematode Pests of Grapevine. In: Fourie, H., Spaull, V.W., Jones, R.K., Daneel, M.S. \& de Waele, D. (Eds.) Nematology in South Africa: A view from the 21st century. Springer International, Switzerland, pp. 345 - 357. https://doi.org/10.1007/978-3$319-44210-5$

Suatmadji, R.W., 1982. Control of root knot nematodes, Meloidogyne javanica, in rootstocks of grapevine, Vitis vinifera, by immersion in nematicide solutions at different temperatures and in hot water. Nematol. Mediterr. 10, 119-125. 
Von Broembsen, S. \& Marais, P.G., 1978. Eradication of Phytophthora cinnamomi from grapevine by hot water treatment. Phytophylactica 10 , $25-27$.
Waite, H. \& Morton, L., 2007. Hot water treatment, trunk diseases and other critical factors in the production of high-quality grapevine planting material. Phytopathol. Mediterr. 46, 5-17. 